\title{
A modern surgical smoke evacuator for the challenges of today's operating room
}

\author{
Crystal D Ricketts, Shawn K Horner, Jeffrey W Clymer* and Paul R Borgmeier \\ Ethicon, Inc., Cincinnati OH, USA
}

\begin{abstract}
Background: In the current conditions of the COVID-19 pandemic, it is imperative that surgical plume be effectively removed from both open and laparoscopic procedures, especially when energized devices are being utilized. This study evaluated a new Megadyne Smoke Evacuator, to establish its performance in removing smoke, while improving visibility at the surgical site and lessening the risk of staff exposure to the components of surgical smoke, such as chemicals, particulates, viruses and bacteria.

Methods: The smoke evacuator was evaluated by nurses and surgeons in both open and laparoscopic simulated procedures. Nurses were asked to setup and operate the smoke evacuator, and surgeons performed a variety of electrosurgery procedures in an animate porcine model. Both groups were then asked to evaluate the device via a questionnaire.

Results: Over $90 \%$ of the nurses $(n=18)$ agreed that the Megadyne Smoke Evacuator was easy to set up, understand the settings and change the filter. Surgeons agreed that the smoke evacuator operated effectively in open $(94 \%, 17 / 18)$ and laparoscopic $(100 \%, 16 / 16)$ procedures.

Conclusion: Given the risks inherent in performing surgery today, it is more important than ever to use an effective method of smoke evacuation. With an ULPA filter capable of blocking particles as small as $20 \mathrm{~nm}$ with high efficiency, the Megadyne Smoke Evacuator lowers the risk of exposure to small viruses, cellular debris, bacteria and other particles. In addition to having a range of flow rates amenable to open procedures, the device can be used in all steps of laparoscopy, including the process of desufflation.
\end{abstract}

\section{Introduction}

Over $80 \%$ of surgical procedures involve an electrosurgical device used for the cutting and coagulation of tissue [1]. When lasers and electrosurgical devices are employed, they can produce surgical smoke that may be a potential health hazard to perioperative personnel and impair the visibility of the surgical field [2].

The amount of smoke produced is based on several factors which can include the type of surgery and tissue, electrosurgical device and its power settings and mode used [3-5]. According to an Occupational Safety and Health Administration report, every year approximately 500,000 personnel, including surgeons, nurses, anesthesiologists, and surgical technicians, are exposed to the smoke generated by energy source instruments [6]. However, there is no clinical study quantifying the exposure of surgical smoke.

Research has shown that approximately $77 \%$ particle matter in surgical smoke is less than $1.1 \mu \mathrm{m}$ in diameter [7], with a mean diameter of $0.07 \mu \mathrm{m}$, and small particles in the smoke range from $10 \mathrm{~nm}$ to over $1 \mu \mathrm{m}[8]$. In a porcine model, bacterial transmission has been shown to occur when blended current electrosurgery was used on infected tissue [9]. Viral DNA has also been identified in surgical smoke [10], however no studies have demonstrated the transmission of viruses to OR personnel during electrosurgery [11].

To reduce the exposure of surgical smoke, operating rooms have ventilation guidelines and typically use wall suction for smoke evacuation [12]. In addition, to further protect themselves from surgical smoke, surgeons and other OR personnel use a standard surgical mask, laser or high filtration mask, or masks coated with nanoparticles. The smaller smoke particles (less than $5 \mu \mathrm{m}$ ) [13] however, may not be filtered by standard surgical masks, and normal breathing can be impacted by high filtration masks. Wall suction typically lacks sufficient power to clear the smoke at the source of combustion [14].

Surgical smoke protection can also be achieved by the use of dedicated smoke evacuators. Smoke evacuation systems are designed to reduce surgical smoke for a cleaner OR environment and improved surgical site visibility. Additionally, surgical smoke evacuators may reduce the concentration of alcohol vapors from skin preparations at the site of electrosurgical device activation, decreasing operating room fire risk [15].

In light of the recent COVID-19 pandemic, significant concerns have been raised regarding the risk of severe acute respiratory syndrome coronavirus (SARS-CoV-2) dissemination during minimally invasive surgery due to pneumoperitoneum-associated aerosolization of particles and the presence of the virus in blood and stool [16]. Recently surgical societies are suggesting that smoke evacuators should be used in open and laparoscopic surgery [17] to address issues related to surgical smoke.

${ }^{*}$ Correspondence to: Jeffrey W Clymer, Ethicon Inc., 4545 Creek Rd, Cincinnati OH 45242, USA, E-mail: jclymer@its.jnj.com

Key words: smoke evacuation; open surgery; laparoscopy; ULPA filter; particle size; COVID-19

Received: June 05, 2020; Accepted: June 21, 2020; Published: June 23, 2020 


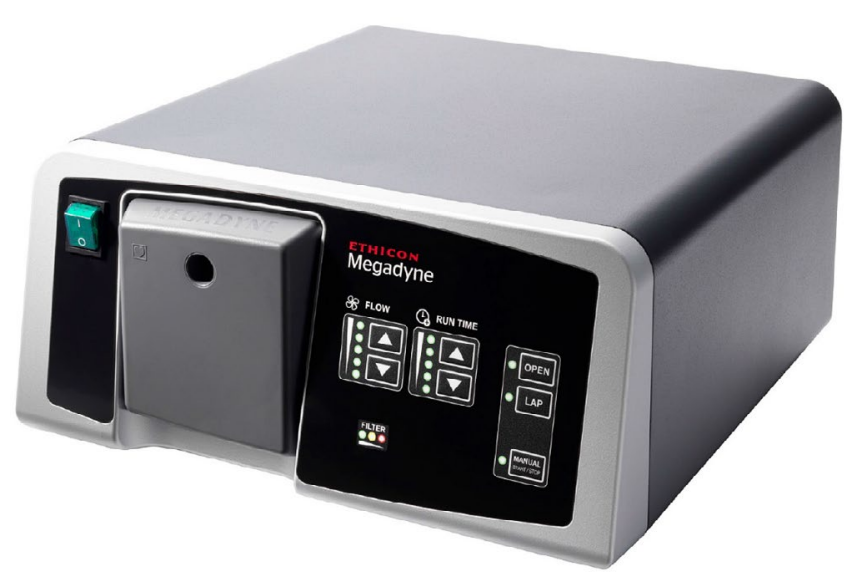

Figure 1: The Megadyne Smoke Evacuator

New features of the Megadyne Smoke Evacuator (Figure 1) include evacuating surgical smoke quietly, passive activation of smoke evacuation when connected via a direct cable to an advanced energy device, removing surgical smoke quickly and sealing off the flow path to maintain pneumoperitoneum pressure while the smoke evacuator is not actively evacuating smoke. This study was undertaken to evaluate both surgeon and nurse experience with the new Megadyne Smoke Evacuator (MESE1), set up, positioning and use of the smoke evacuator under preclinical conditions.

\section{Methods}

The device evaluated in this study was the Megadyne ${ }^{\mathrm{TM}}$ Smoke Evacuator (Model No. MESE1, Ethicon, Inc., Cincinnati, OH, USA), which is indicated for use in removing smoke created at the surgical site. Used with accessories such as sterile smoke evacuation pencils, advanced energy sealing devices and tubing of various sizes in conjunction with electrosurgical generators, the Megadyne Smoke Evacuator is designed for use during open and laparoscopic procedures. Using a scroll pump and multiple stages of filtration, it evacuates surgical smoke both quietly and effectively. An intuitive front panel design allows users to customize both the rate of suction flow and the length of run time after the active electrode is deactivated. Push button selections for open, laparoscopic, and manual modes also are clearly marked and easily accessible. When in laparoscopic mode, the smoke evacuator passively seals off the flow path to help maintain pneumoperitoneum while the smoke evacuator is not active.

The Megadyne filter is a highly efficient ULPA (Ultra Low Particulate Air) and charcoal filtration system designed to capture and filter particulates and microorganisms in the range of 0.1 to 0.2 $\mu \mathrm{m}$ at $99.999 \%$ efficiency. Filter life is automatically displayed to allow optimal filter utilization. An optional fluid trap may also be conveniently attached. Flow rates for the open mode are adjustable from 71 to 118 LPM (liters per minute) and from 5 to 41 LPM in the laparoscopic mode. The smoke evacuator can be activated manually or automatically by monopolar, bipolar, advanced bipolar or ultrasonic devices, with a user-selectable shut-off time up to $30 \mathrm{~s}$ in open mode and $10 \mathrm{~s}$ in laparoscopic mode.

To evaluate the usability of the Megadyne Smoke Evacuator, panels of scrub nurses and surgeons performed simulated surgical procedures in an animal model. Afterwards, nurses were asked about the ease of setup, usability and tear down, while the surgeons were asked to provide feedback on the settings and modes used, and the ability of the smoke evacuator to remove smoke. All participants had the opportunity to review the instructions for use prior to beginning their tasks.

\section{Nurses}

Nurses were asked to setup the smoke evacuator in a porcine model for both open and laparoscopic procedures. They were then asked to attach an Ultra Vac Smoke Evacuation Pencil (211010EC, Ethicon, Cincinnati $\mathrm{OH}$ ) for the open procedural section and lap tubing and lap electrode device for the laparoscopic procedure, followed by adjusting the flow and run time. Nurses were also asked to adjust the settings as needed when a surgeon performed different tasks. These activities mimicked tasks performed during a normal surgical procedure (e.g., setting up the smoke evacuator, entering preferences, adjusting flow, etc.).

\section{Surgeons}

Surgeons were asked to cut and coagulate tissue in an open porcine model with a monopolar device and the smoke evacuator. In addition, the Megadyne Endopath Bipolar Forceps (4010J, Ethicon, Cincinnati $\mathrm{OH}$ ) was used to coagulate tissue. Open surgical procedures performed in a porcine model included a colonic mobilization, omentectomy, skin flap, small bowel resection or total hysterectomy with or without oophorectomy, depending on the surgeon's specialty. Laparoscopic tasks included using a monopolar pencil to coagulate the surface of the liver and stomach. A small defect in the stomach or liver was also made and coagulation was used to create smoke. The surgeon instructed the nurse to make adjustments based on their preferred smoke evacuator settings to accomplish each task.

After the procedures, the surgeons evaluated the generator via predefined questionnaires on attributes of the smoke evacuator including its ability to remove smoke and aerosols from the surgical site in open and lap procedures. Each study participant signed a consent form prior to the interview.

Animal procedures were approved by the local Institutional Animal Care and Use Committees and conducted in accordance with the Guide for the Care and Use of Laboratory Animals and applicable animal welfare regulations in AAALAC-accredited facilities.

\section{Results}

A total of 18 nurses and 18 surgeons participated in the open simulated experience, and 18 nurses and 16 surgeons participated in the laparoscopic simulation. Surgeons represented the areas of gynecological, colorectal, and general surgery. All nurses and surgeons had previous experience with smoke evacuators, with the most familiarity with Medtronic RapidVac, Stryker Neptune, ConMed 1200, Airseal or Minivac.

Results of the questionnaires are given in Table 1 for the nurses and Table 2 for the surgeons. One hundred percent of the nurses agreed that overall set up, control and use of the smoke evacuator was acceptable. Over $90 \%$ of the nurses indicated that the smoke evacuator was easy to connect to and disconnect from the portable RF sensor. Over $90 \%$ of surgeons agreed that the Megadyne smoke evacuator removed smoke acceptably in open and laparoscopic procedures. Ninety-four percent of the surgeons rated the smoke evacuator as acceptable.

\section{Discussion}

Surgical smoke is composed of cellular debris consisting of carbonaceous particulates, blood and tissue fragments, and possibly viruses and bacteria [18]. Exposure to surgical smoke may be associated 
Table 1. Summary of Results from the Nurses Questionnaire on the Megadyne Smoke Evacuator

\begin{tabular}{|l|c|}
\hline Statement & \% Agree \\
\hline $\begin{array}{l}\text { The smoke evacuator removed smoke and aerosols from } \\
\text { the surgical site. }\end{array}$ & $100 \%(18 / 18)$ \\
\hline Manual control of the smoke evacuator was acceptable & $100 \%(18 / 18)$ \\
\hline The filter life indicator was understandable & $100 \%(18 / 18)$ \\
\hline Changing the smoke evacuator filter was acceptable & $100 \%(18 / 18)$ \\
\hline $\begin{array}{l}\text { The overall cleanup of the smoke evacuator (i.e. removal } \\
\text { and disposal of the filter and/or fluid trap) was easy. }\end{array}$ & $100 \%(18 / 18)$ \\
\hline $\begin{array}{l}\text { The smoke evacuator was easy to connect to and disconnect } \\
\text { from the portable RF sensor. }\end{array}$ & $94 \%(17 / 18)$ \\
\hline
\end{tabular}

Table 2. Summary of Results from the Surgeon Questionnaire on the Megadyne Smoke Evacuator

\begin{tabular}{|l|c|}
\hline Statement & \% Agree \\
\hline $\begin{array}{l}\text { The ability of the smoke evacuator to remove smoke in } \\
\text { open procedures was acceptable. }\end{array}$ & $94 \%(17 / 18)$ \\
\hline $\begin{array}{l}\text { The ability of the smoke evacuator to remove smoke in } \\
\text { laparoscopic procedures was acceptable. }\end{array}$ & $100 \%(16 / 16)$ \\
\hline $\begin{array}{l}\text { The smoke evacuator removed smoke and aerosols from } \\
\text { the surgical site. }\end{array}$ & $89 \%(16 / 18)$ \\
\hline $\begin{array}{l}\text { The overall performance of the smoke evacuator was } \\
\text { acceptable. }\end{array}$ & $94 \%(17 / 18)$ \\
\hline
\end{tabular}

with an increase in the risk of acute and chronic pulmonary conditions, acute headaches, irritation and soreness of the eyes, nose and throat [2]. In a nurses health study by Le Moual, OR nurses had a significant association with severe persistent asthma, compared with non-OR nurses, although it was suggested that the actual etiology might be disinfectants or cleaning agents, not surgical smoke [19].

Surgical smoke, and in particular smoke from laser surgery, has been shown to contain whole, intact virions [20]. The DNA of both HIV (Human Immunodeficiency Virus) and HPV (Human Papillomavirus) has been isolated from laser surgery smoke [21-23], and demonstrated that virus could be transmitted to cultured cells [24]. Whole virus with the ability to cause infection has been identified in electrosurgery [25]. Even though a number of papillomatosis and verrucae transmission anecdotal cases have been reported via laser surgery [26-28], there are no confirmed cases of viral transmission.

In a study by Wang, data show that the amount of surgical smoke that one is exposed to can vary significantly by position. Levels of particulates, termed PM2.5, after a single $40 \mathrm{~cm}$ electrosurgical cut may reach 'unhealthy' or 'very unhealthy' for the chief surgeon [29]. In this study the assistant inhaled less than half of that amount, and the scrub nurse was exposed to nearly no smoke.

As shown in table 3, the particle size of smoke produced by energized devices extends over three orders of magnitude [30], and generally is smaller than typical biologically produced aerosols, such as from a cough that ranges 0.35 to $10 \mu \mathrm{m}$ [31].

Free virus particles have been shown to be as small as $20 \mathrm{~nm}$ (Table 4). Based on the characteristics of ULPA filters, particles this small should be blocked, as the efficiency of the filter is extremely high both above and below the MPPS (Most Penetrating Particle Size). It has been suggested that viable virions may be aerosolized by surgical devices, but laser surgery is the only energy surgery that has been associated with viral transmission and infection. Laser surgery generates small submicron particles, but has also been shown to create particles capable of transmitting viruses with diameters of 7 to $55 \mu \mathrm{m}$ [20]. Smoke evacuators with ULPA filters are capable of blocking viruses of this size.
The use of filtration has been shown to effectively prevent aerosol transmission of Porcine Reproductive and Respiratory Syndrome Virus (PRRSV). In a study by Dee, High-Efficiency Particulate Air (HEPA) filters were used to prevent naïve pigs from being infected by pigs with PRRSV. In this study, a particle size of the virus-containing aerosols (300 to $3000 \mathrm{~nm}$ ) was used, while other methods of filtering permitted transmission of particles in this range, and were ineffective. The authors stated that the HEPA filters were effective in preventing air-borne viral transmission [36].

A surgical face mask is capable of filtering most aerosolized particles; not all masks however are individually fitted so there can be areas which allow for the inhalation of particles. An N95 respirator mask can achieve $>95 \%$ filter efficiency when tested with $300 \mathrm{~nm}$ sized particles, and a grade 100 respirator mask can achieve $>99.97 \%$ filter efficiency.

The Megadyne Smoke Evacuator uses two filters; a charcoal filter that removes molecular odors via adsorption and a fiberglass ULPA (Ultra Low Particulate Air) filter that blocks particles via a tortuous path. ULPA filters are rated for their efficiency at removing particles at the MPPS. As can be observed in figure 2, the MPPS for the ULPA filter used in the Megadyne Smoke Evacuator is in the range of 100-200 nm, and the minimum efficiency is greater than $99.9999 \%$. Larger particles are blocked by the filter at even higher efficiency, but somewhat counter-intuitively smaller particles are also filtered at higher efficiency. The reason for this is that smaller particles have a lower motive force and tend to have insufficient momentum to make it through the ULPA

Table 3. Particle size of smoke produced by energized devices

\begin{tabular}{|c|c|}
\hline Instrument & Particle Size \\
\hline Electrosurgery & $7-420 \mathrm{~nm}$ \\
\hline Laser & $100-800 \mathrm{~nm}$ \\
\hline Ultrasonic & $350-6500 \mathrm{~nm}$ \\
\hline
\end{tabular}

Table 4. Size of viral particles

\begin{tabular}{|c|c|c|c|}
\hline Virus & Name & Diameter & Reference \\
\hline HAV & Hepatitis A Virus & $20 \mathrm{~nm}$ & 32 \\
\hline HEV & Hepatitis E Virus & $30 \mathrm{~nm}$ & 32 \\
\hline HBV & Hepatitis B Virus & $40 \mathrm{~nm}$ & 32 \\
\hline HPV & Human Papilloma Virus & $55 \mathrm{~nm}$ & 33 \\
\hline HCV & Hepatitis C Virus & $60 \mathrm{~nm}$ & 33 \\
\hline SARS-CoV-2 & COVID-19 Virus & $60-140 \mathrm{~nm}$ & 34 \\
\hline HIV & Human Immunodeficiency Virus & $100 \mathrm{~nm}$ & 35 \\
\hline
\end{tabular}

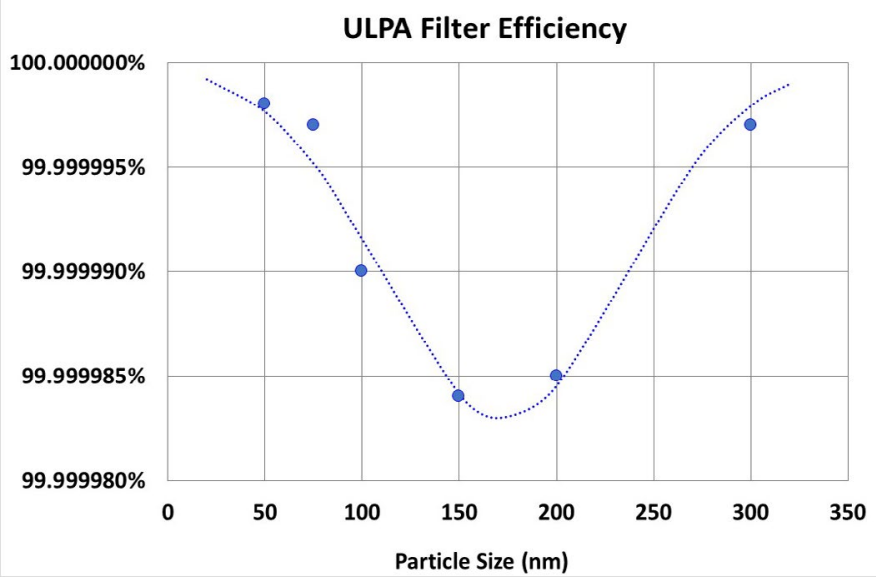

Figure 2. Filter efficiency for the ULPA filter used in the Megadyne Smoke Evacuator. 
filter's tortuosity. Thus ULPA filters are efficient at removing particles as small as $50 \mathrm{~nm}$ (Figure 2) and the filter in the Megadyne Smoke Evacuator is $99.9999 \%$ efficient down to $20 \mathrm{~nm}$. It is increasingly difficult to measure efficiency as particle size becomes smaller.

The Megadyne Smoke Evacuator can be used in both open and laparoscopic surgery. During laparoscopic surgery the peritoneal cavity is insufflated with $\mathrm{CO}_{2}$, creating what is termed a pneumoperitoneum. The gas is typically insufflated at a rate of 4-6 liters per minute to a pressure of $10-20 \mathrm{~mm} \mathrm{Hg}$, and pneumoperitoneum is maintained with a flow of 0.2-0.4 liters per minute [37]. After surgery, the pneumoperitoneum is typically emptied into the OR atmosphere. With concern over potential contamination of the insufflation gas, it is now strongly recommended that the $\mathrm{CO}_{2}$ be emptied via a smoke evacuation unit with an ULPA filter [17]. With a flow rate of over 40 liters per minute in laparoscopic mode, the Megadyne Smoke Evacuator is capable of removing the insufflation gas quickly, while capturing virtually all particulate matter.

The Megadyne Smoke Evacuator features a number of improvements over the previous models. When activated, it is quieter with both a lower volume $(50 \pm 10 \mathrm{~dB})$ and a lower pitch, which makes the sound less noticeable. The device can also be set to operate intermittently, so that there is virtually no noise when smoke is not being evacuated. This intermittent operation in laparoscopic mode is also helpful in maintaining a constant peritoneum pressure; the insufflation device does not have to work as hard because it does not have to constantly infuse $\mathrm{CO}_{2}$. The start-up time to full flow during intermittent operation is substantially faster within a quarter-second to 60 LPM in open mode and within a half-second to 15 LPM in lap mode, so that visibility in the field of view is impaired for a shorter period of time. Previous versions of the evacuator could only be triggered by monopolar or simple bipolar electrosurgery, whereas now the Megadyne Smoke Evacuator can also be activated by both advanced bipolar and ultrasonic instruments.

In preclinical testing both surgeons and nurses indicated that the Megadyne ${ }^{\mathrm{TM}}$ Smoke Evacuator performed smoke evacuation as expected and was easy to set up and use. In addition to the removal of potentially hazardous chemicals and biological materials, the Megadyne Smoke Evacuator substantially improves visibility during surgery. As can be seen in figure 3, even with a low plumage energy device, lack of smoke evacuation noticeably decreases visual acuity. The effect becomes more prominent with devices or conditions that produce higher levels of particulate smoke.

Several states are in various stages of developing legislation on 'smoke free' operating environments. So far only two states have passed these guidelines [38,39]. Due to the COVID 19 outbreak it is expected that other states, and likely nations around the world, will soon be developing OR smoke evacuation guidance. Awareness of the health
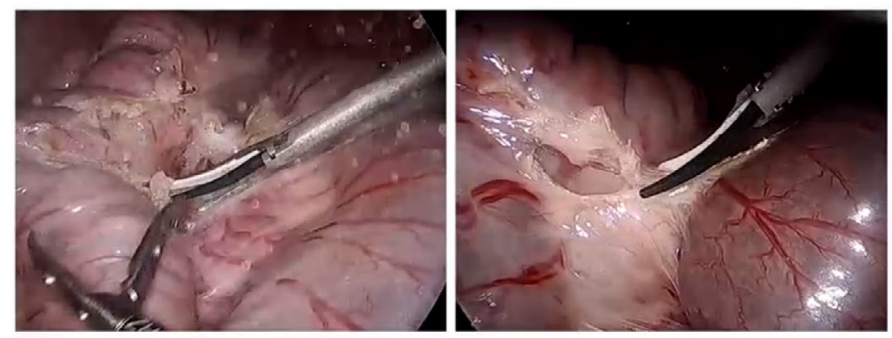

Figure 3. Comparison of visual acuity during low plume energy application without (left) and with (right) smoke evacuation. hazards of surgical smoke should be addressed by education, which in turn may increase the use of smoke extraction devices. Educating and training nurses has been shown to be associated with good compliance, hence this may be a path forward while states investigate mandatory guidelines to use smoke evacuation devices.

\section{References}

1. Meeuwsen F, Guédon A, Klein J, Elst MvD, Dankelman J, et al. (2019) Electrosurgery: short-circuit between education and practice. Minimally Invasive Therapy \& Allied Technologies 28: 247-253.

2. Okoshi K, Kobayashi K, Kinoshita K, Tomizawa Y, Hasegawa S, et al. (2015) Health risks associated with exposure to surgical smoke for surgeons and operation room personnel. Surgery today 45: 957-965.

3. Barrett WL, Garber SM (2003) Surgical smoke: a review of the literature. Surg Endosc 17: 979-987. [Crossref]

4. Gatti JE, Bryant CJ, Noone RB, Murphy JB (1992) The mutagenicity of electrocautery smoke. Plast Reconstr Surg 89: 781-784. [Crossref]

5. Wu YC, Tang CS, Huang HY, Liu CH, Chen YL, et al. (2011) Chemical production in electrocautery smoke by a novel predictive model. Eur Surg Res 46: 102-107. [Crossref]

6. Safety O (2008) Health Topics: Laser/Electrosurgery Plume. Washington, DC: Occupational Safety And Health Administration.

7. Liu Y, Song Y, Hu X, Yan L, Zhu X (2019) Awareness of surgical smoke hazards and enhancement of surgical smoke prevention among the gynecologists. J Cancer 10: 2788. [Crossref]

8. Brüske-Hohlfeld I, Preissler G, Jauch KW, Pitz M, Nowak D, et al. (2008) Surgical smoke and ultrafine particles. J Occup Med Toxicol 3: 31. [Crossref]

9. Schultz L (2015) Can efficient smoke evacuation limit aerosolization of bacteria? AORN J 102: 7-14. [Crossref]

10. Christie D, Jefferson P, Ball D (2005) Diathermy smoke and human health. Anaesthesia 60: 632-632. [Crossref]

11. Lindsey C, Hutchinson M, Mellor G (2015) The nature and hazards of diathermy plumes: a review. AORN J 101: 428-442. [Crossref]

12. Schulster L, Chinn RYW, CDC; HICPAC (2003) MMWR: Guidelines for Environmental Infection Control in Health-Care Facilities: Recommendations of $\mathrm{CDC}$ and the Healthcare Infection Control Practices Advisory Committee (HICPAC). MMWR Recomm Rep 52: 1-42. [Crossref]

13. Mowbray N, Ansell J, Warren N, Wall P, Torkington J (2013) Is surgical smoke harmful to theater staff? A systematic review. Surg Endosc 27: 3100-3107. [Crossref]

14. Hill D, O'Neill J, Powell R, Oliver D (2012) Surgical smoke-a health hazard in the operating theatre: a study to quantify exposure and a survey of the use of smoke extractor systems in UK plastic surgery units. J Plast Reconstr Aesthet Surg 65: 911916. [Crossref]

15. Carmichael H, Samuels JM, Wikiel KJ, Robinson TN, Barnett Jr CC, et al. (2019) Surgical smoke evacuators reduce the risk of fires from alcohol-based skin preparations. Surg Laparosc Endosc Percutan Tech 29: e94-e97. [Crossref]

16. Zhang W, Du RH, Li B, Zheng XS, Yang XL, et al. (2020) Molecular and serological investigation of 2019-nCoV infected patients: implication of multiple shedding routes. Emerging microbes \& infections 9: 386-389. [Crossref]

17. Francis N, Dort J, Cho E, Feldman L, Keller D, et al. (2020) SAGES and EAES recommendations for minimally invasive surgery during COVID-19 pandemic. Surg Endosc 34: 2327-2331. [Crossref]

18. González-Bayón L, González-Moreno S, Ortega-Pérez G (2006) Safety considerations for operating room personnel during hyperthermic intraoperative intraperitoneal chemotherapy perfusion. Eur J Surg Oncol 32: 619-624. [Crossref]

19. Le Moual N, Varraso R, Zock JP, Henneberger P, Speizer FE, et al. (2013) Are operating room nurses at higher risk of severe persistent asthma?: The Nurses' Health Study. J Occup Environ Med 55: 973. [Crossref]

20. Matchette LS, Vegella TJ, Faaland RW (1993) Viable bacteriophage in CO2 laser plume: aerodynamic size distribution. Lasers Surg Med 13: 18-22. [Crossref]

21. Garden JM, O'Banion MK, Shelnitz LS, Pinski KS, Bakus AD, et al. (1988) Papillomavirus in the vapor of carbon dioxide laser-treated verrucae. JAMA 259: 11991202. [Crossref] 
22. Ferenczy A, Bergeron C, Richart RM (1990) Carbon dioxide laser energy disperses human papillomavirus deoxyribonucleic acid onto treatment fields. Am J Obstet Gynecol 163: 1271-1274. [Crossref]

23. Kashima HK, Kessis T, Mounts P, Shah K (1991) Polymerase chain reaction identification of human papillomavirus DNA in $\mathrm{CO} 2$ laser plume from recurrent respiratory papillomatosis. Otolaryngol Head Neck Surg 104: 191-195. [Crossref]

24. Baggish MS, Polesz BJ, Joret D, Williamson P, Refai A (1991) Presence of human immunodeficiency virus DNA in laser smoke. Lasers Surg Med 11: 197-203. [Crossref]

25. Sawchuk WS, Weber PJ, Lowy DR, Dzubow LM (1989) Infectious papillomavirus in the vapor of warts treated with carbon dioxide laser or electrocoagulation: detection and protection. J Am Acad Dermatol 21: 41-49. [Crossref]

26. Gloster HM, Roenigk R (1885) Risk of acquiring human papillomavirus from the plume produced by the carbon dioxide laser in the treatment of warts. $J$ Am Acad Dermatol 32: 436-441. [Crossref]

27. Hallmo P, Naess O (1991) Laryngeal papillomatosis with human papillomavirus DNA contracted by a laser surgeon. Eur Arch Otorhinolaryngol 248: 425-427. [Crossref]

28. Rioux M, Garland A, Webster D, Reardon E (2013) HPV positive tonsillar cancer in two laser surgeons. J Otolaryngol Head Neck Surg 42: 54. [Crossref]

29. Wang HK, Mo F, Ma CG, Dai B, Shi GH, et al. (2015) Evaluation of fine particles in surgical smoke from an urologist's operating room by time and by distance. Int Urol Nephrol 47: 1671-1678. [Crossref]
30. Fan JKM, Chan FSY, Chu KM (2009) Surgical smoke. Asian J Surg 32: 253-257. [Crossref]

31. Lindsley WG, Pearce TA, Hudnall JB, Davis KA, Davis SM, et al. (2012) Quantity and size distribution of cough-generated aerosol particles produced by influenza patients during and after illness. J Occup Environ Hyg 9: 443-449. [Crossref]

32. Board SS, Council NR (1999) Size limits of very small microorganisms: proceedings of a workshop. National Academies Press.

33. Keyvani H, Fazlalipour M, Monavari SHR, Mollaie HR (2012) Hepatitis C virusproteins, diagnosis, treatment and new approaches for vaccine development. Asian Pac J Cancer Prev 13: 5917-5935. [Crossref]

34. Zhu N, Zhang D, Wang W, Li X, Yang B, et al. (2020) A novel coronavirus from patients with pneumonia in China, 2019. $N$ Engl J Med 382:727-733. [Crossref]

35. Blood GAC (2016) Human immunodeiciency virus (HIV). Transfus Med Hemother 43: 203. [Crossref]

36. Dee SA, Deen J, Cano JP, Batista L, Pijoan C (2006) Further evaluation of alternative air-filtration systems for reducing the transmission of porcine reproductive and respiratory syndrome virus by aerosol. Can J Vet Res 70: 168. [Crossref]

37. Perrin M, Fletcher A (2004) Laparoscopic abdominal surgery. Continuing Education in Anaesthesia, Critical Care \& Pain 4: 107-110.

38. Scroggins RW (2019)Surgical smoke evacuation laws how can you get ahead of the coming legislative efforts? Paper presented at: International Laser Safety Conference.

39. Qiao Y, Andrews AJ, Christen CE, Olson BA, Khariwala S, et al. (2020) Morphological Characterization of Particles Emitted from Monopolar Electrosurgical Pencils. Journal of Aerosol Science: 105512.

Copyright: $\odot 2020$ Ricketts CD. This is an open-access article distributed under the terms of the Creative Commons Attribution License, which permits unrestricted use, distribution, and reproduction in any medium, provided the original author and source are credited. 